\title{
Temporal changes in fish abundance in response to hydrological variability in a dryland floodplain river
}

\author{
Stephen R Balcombe ${ }^{\mathrm{A}, \mathrm{B}}$ and Angela H Arthington ${ }^{\mathrm{A}}$

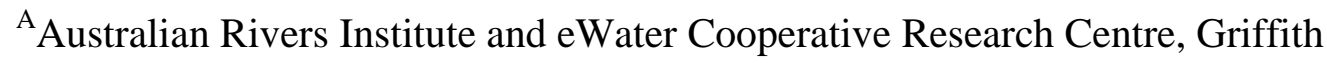 \\ University, Nathan, Queensland, 4111, Australia.

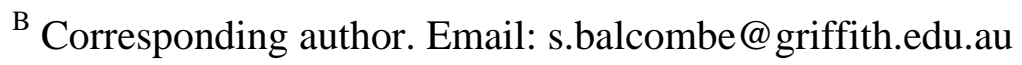

Running Headline: Fish abundance patterns in a dryland river

\begin{abstract}
Riverine fish living in unpredictable flow environments, tend to be ecological generalists with traits that allow them to persist under highly variable and often harsh conditions associated with hydrological variation. Cooper Creek, an Australian dryland river, is characterised by extreme flow variability, especially in the magnitude, timing and duration of channel flows and floods, which, if they occur, do so mainly in summer. This study examined the influence of hydrological variability on fish assemblages and abundance in four waterholes in the Windorah reach of Cooper Creek over eight occasions between 2001 and 2004. Antecedent flows had marked influences on fish species richness and assemblage structure. Following high summer flows, all waterholes supported a rich and abundant fish fauna, whereas, fewer species and lower numbers were recorded following periods of zero channel flow. Recruitment of three of the four most common and abundant species was enhanced when intermittent flows inundated backwater and floodplain habitats that provide a food-rich environment. Opportunistic responses to rising channel flows and occasional large floods in Cooper Creek help to explain the prominent "boom“
\end{abstract}


patterns of fish production in this arid-zone river, while low-level recruitment during periods of low or no flow maintains populations of some species through the "bust".

Additional keywords: desert rivers, floodplains, drought, habitat structure, spatial scale 


\section{Introduction}

Arid and semi-arid (hereafter dryland) regions encompass about $47 \%$ of the global land surface (Middleton and Thomas 1997). Despite their low annual rainfall $(<500$ $\mathrm{mm}$ ), many desert landscapes are traversed by rivers of great importance to the ecology of the surrounding ecosystems and human settlements (Postel 1999; Kingsford 2006). Dryland regions represent 75\% of land area in Australia, where inland floodplain rivers such as Cooper Creek and the Diamantina River exhibit some of the most variable and unpredictable flow regimes on earth (Walker et al. 1995; Puckridge et al. 1998). Even so, these highly variable inland rivers support a diverse aquatic fauna including local endemics, and very productive native fish assemblages (Bunn et al. 2003; 2006a; Arthington et al. 2005).

Cooper Creek is largely unregulated and therefore provides an ideal system for exploring the influence of natural flow variability (sensu Poff et al. 1997) and extreme flow events (floods and dry spells with no river flow) on the ecology of desert fishes. During extended dry periods between occasional large floods, fish survive in isolated waterholes within channels and on the floodplain, where the composition of assemblages and species abundance patterns typically vary widely at the reach and waterhole scale in relation to topography, floodplain size and waterhole setting, habitat structure/connectivity and water quality conditions (Puckridge et al. 2000; Arthington et al. 2005) as observed in many of the world's floodplain rivers (Rodriguez and Lewis 1997; Tejerina-Garro et al. 1998; Jackson et al. 2001; Welcomme 2001). When floods do occur they mostly coincide with high summer temperatures (Kingsford et al. 1999; Balcombe et al. 2007) and this coupling of flow and thermal regime is thought to be an important requirement, if not a cue, for spawning and the subsequent pulses of fish recruitment that typify many floodplain 
river fish assemblages (King et al. 2003; Arrington and Winemiller 2004; Balcombe et al. 2006, 2007; Welcomme et al. 2006a). However, the intermittency of flooding and the long dry spells between large flood events (up to 2 years in some parts of Cooper Creek) imply low or zero recruitment during these dry spells, potentially causing declines in populations if fish depend upon flooding for successful recruitment.

An alternative to the "flood pulse recruitment" strategy is to spawn during spring and early summer periods of low, in-channel flows when even small freshets can create inundated backwater habitats suitable for spawning, larval growth and juvenile recruitment. This “low flow recruitment” strategy is a well-documented adaptation of small fish species to variable flow patterns in the Murray-Darling river system (Humphries et al. 1999; Balcombe et al. 2006) and coastal rivers of eastern Australia (Milton and Arthington 1984, 1985; Pusey et al. 2001, 2002, 2004). It has been argued that the early spring and summer months present an ideal 'window of opportunity’ (Cushing, 1990) for spawning and larval growth in warm, shallow, productive stream habitats and backwaters that typically offer shelter from predators, and high growth and recruitment potential (Humphries et al. 1999; King 2004; Pusey et al. 2004).

This paper examines the influence of hydrological variability in general, and patterns of flooding in particular, on the structure of fish assemblages and abundance patterns of Cooper Creek fishes. We examined spatial and temporal variations in fish assemblage structure, species richness, abundance and population size structure in four waterholes in the vicinity of Windorah (mid-Cooper Creek catchment) over a four-year period, 2001-2004. We related patterns of assemblage and population variation to antecedent hydrological conditions, water temperature and water quality 
characteristics. Based upon field observations and past studies of fish in floodplain river systems, we made the following predictions. 1. Fish abundance and assemblage structure in isolated waterholes will be strongly influenced by antecedent hydrology and seasonal variations in water temperature. 2. Temporal patterns in population sizestructure will reflect antecedent hydrology and season. 3. Flood events will have particular significance for recruitment success but species may vary in their response to flooding and dry periods.

\section{Materials and methods}

\section{Study area}

The Cooper Creek catchment has a semi-arid climate with mean annual rainfall varying from $400-500 \mathrm{~mm}$ in the headwaters to $<100 \mathrm{~mm}$ at its entry to Lake Eyre (Puckridge 1999; Bunn et al. 2003). At Currareva, near Windorah (S 25²428, E $142^{\circ} 734$, Fig. 1) mean annual discharge is $3.05 \mathrm{~km}^{3} \mathrm{yr}^{-1}\left(97 \mathrm{~m}^{3} \mathrm{~s}^{-1}\right)$. The timing and volume of rain events are highly variable among years, hence, inter-annual variability in streamflow is high (Puckridge et al. 1998; 2000). For its size, Cooper Creek has one of the most unpredictable flow regimes in the world (Puckridge et al. 1998; Knighton and Nanson 2001). Most stream flow is generated by seasonal monsoon rainfall in the northern headwater areas of the catchment and periodic local rainfall, resulting in highly variable patterns of floodplain inundation, and flow pulses that remain within channels in some years (Knighton and Nanson 1994; Puckridge et al. 1998). Episodes of flooding can inundate tens of thousands of square kilometres of floodplain (equivalent to 35\% of the catchment); and serve to reconnect anastomosing channels, distributaries and isolated waterholes. Floods that breach the banks are separated by long dry periods that can last up to 21 months based on 49 years of 
record at Currareva (Bunn et al. 2003). During these extended periods of occasional channel flows or no flow, Cooper Creek dries down to mosaics of highly turbid 'waterholes' that typically take the form of isolated, relatively deep segments of channel located at points of flow convergence (Knighton and Nanson 1994). Many waterholes hold water for more than 12 months in the absence of surface flow but most dry to approximately $10 \%$ of their bankfull volume within 23 months as a consequence of high evaporation rates (Hamilton et al. 2005). In Cooper Creek, isolated waterholes in channels and on the floodplain serve as refugia (Morton et al. 1995; Magoulick and Kobza 2003), providing the only habitat sustaining aquatic biota between the wetter periods that generate channel flows, or occasionally, large floods (Arthington et al. 2005, Bunn et al. 2006b). Daily and seasonal temperatures vary widely. Mean daily maximum air temperatures at Windorah range from $38.1^{\circ} \mathrm{C}$ in January to $21.4^{\circ} \mathrm{C}$ in July and mean daily minima from $24^{\circ} \mathrm{C}$ in January to $7^{\circ} \mathrm{C}$ in July (Bureau of Meteorology). Water temperatures track these patterns.

Prior to the first sampling occasion (April 2001), the last major flood in Cooper Creek occurred in February-March 2000, with peak discharge of $13600 \mathrm{~m}^{3} \mathrm{~s}^{-1}$ (Fig. 2), connecting all study waterholes. There was only one other major flood within the study period, occurring in January 2004 and peaking at $9000 \mathrm{~m}^{3} \mathrm{~s}^{-1}$ (Fig. 2). In addition to the two large floods, there were a number of in-channel flows prior to and within the study period. Prior to the first sampling occasion in April 2001, there were four flow pulses, the two largest ones being $1200 \mathrm{~m}^{3} \mathrm{~s}^{-1}$ and $1400 \mathrm{~m}^{3} \mathrm{~s}^{-1}$ in November and December 2000, respectively. Two smaller pulses followed in January (400 $\mathrm{m}^{3} \mathrm{~s}^{-}$ ${ }^{1}$ ) and February $\left(170 \mathrm{~m}^{3} \mathrm{~s}^{-1}\right)$ 2001. These pulses resulted in continuous flow linking the three in channel waterholes (Murken, Mayfield and Glenmurken) from November 2000 through to February 2001, while Shed Waterhole would have been flowing for 
the same period, even through it is situated on a different distributary channel that usually receives water from the Barcoo River (see Fig. 1). After the February 2001 flow pulse, there was no further flow in Cooper Creek until December $2001\left(770 \mathrm{~m}^{3} \mathrm{~s}^{-}\right.$ $\left.{ }^{1}\right)$ and January $2002\left(280 \mathrm{~m}^{3} \mathrm{~s}^{-1}\right)$. Following these flows, Cooper Creek remained dry until February 2003 when it received a small flow $\left(330 \mathrm{~m}^{3} \mathrm{~s}^{-1}\right)$, another in March 2003 $\left(750 \mathrm{~m}^{3} \mathrm{~s}^{-1}\right)$ and a small pulse in April $2003\left(40 \mathrm{~m}^{3} \mathrm{~s}^{-1}\right)$. From April 2003 onward there was no flow until the major flood of January $2004\left(9000 \mathrm{~m}^{3} \mathrm{~s}^{-1}\right)$, a small flow-pulse in February $2004\left(450 \mathrm{~m}^{3} \mathrm{~s}^{-1}\right)$ and a much smaller pulse in May $2004\left(10 \mathrm{~m}^{3} \mathrm{~s}^{-1}\right)$.

During the study period, daily maximum air temperatures cycled on a typical annual pattern with daily summer maxima often above $40^{\circ} \mathrm{C}$ between November and March (Fig. 2). At these times daily minima were rarely below $15^{\circ} \mathrm{C}$. Minimum winter temperatures were generally recorded between June and August with daily maxima mostly below $15^{\circ} \mathrm{C}$ and daily minima rarely above $10^{\circ} \mathrm{C}$. At times of fish sampling, waterhole water temperatures were continuously logged over 24-h periods and the temperature ranges of the four waterholes were as follows - April 2001: 20.327.1 ${ }^{0} \mathrm{C}$; September 2001: $19.4-28.2^{0} \mathrm{C}$; October 2002: $18.1-29^{0} \mathrm{C}$; May 2003: $18.2-$ 22. $3^{0} \mathrm{C}$; March 2004: $26-33.1^{0} \mathrm{C}$; June 2004: $15.5-19^{0} \mathrm{C}$; October 2004: $19.6-33.1^{0} \mathrm{C}$; December 2004: $24.2-30.1^{0} \mathrm{C}$. Hence, water temperatures generally ranged midway between daily maximum and minimum air temperatures (see Fig. 2).

\section{Fish sampling}

Fish abundance and assemblage structure and the size frequency distributions of four fish species were assessed in four waterholes (Glenmurken, Mayfield, Murken and Shed) of Cooper Creek below the confluence of the Thomson and Barcoo Rivers near 
Windorah, western Queensland (Fig. 1). The physical characteristics of these four waterholes are representative of the types of waterhole refugia present in the midCooper Creek catchment (Bunn et al. 2006b; Balcombe et al. 2007).

The fish assemblage within each of the four waterholes was sampled using three fyke nets and a single beach seine haul. Fyke wing width and sampling duration were recorded for each net, for the subsequent calculation of catch per unit effort (CPUE), where CPUE represents the sum total of individuals of each species collected from three fyke nets set for 19 hours with the wing entrance $10 \mathrm{~m}$ in width. Fyke nets (13 mm mesh) captured both small and large individuals of all 12 fish species known to live in these waterholes (Arthington et al. 2005). Beach seining (9.5 mm mesh) was used as an additional method to ensure that very small individuals, such as juvenile carp gudgeons (Hypseleotris spp.) were not missed from species richness and abundance estimates. Further details of the sampling methods can be found in Arthington et al. (2005).

To gain some insight into the influence antecedent hydrology and season/temperature have on fish recruitment and hence, patterns of abundance, we also recorded the length frequency distributions of the four most abundant and commonly occurring fish species across all sampling times. The four species were the two plotosid catfishes: silver tandan, Porochilus argenteus and Hyrtl’s tandan, Neosilurus hyrtlii; bony bream, Nematalosa erebi and Lake Eyre golden perch, Macquaria sp. B. Recruitment dynamics of Hyrtl's tandan and Macquaria ambigua (closely related to Macquaria sp. B) have been documented in the Warrego River, a major dryland tributary of the upper Darling River (Balcombe et al. 2006). There is, however, very little information on the recruitment patterns of $P$. argenteus and the Lake Eyre golden perch, Macquaria sp. B. Furthermore, there is no detailed 
information on ageing and growth of these four species and hence, the timing of spawning and actual age of juvenile recruits is somewhat speculative. However, based upon our experience of fish sampling in isolated waterholes in the Lake Eyre Basin under varying hydrological conditions and published data for these or similar species (see Pusey et al. 2004; Balcombe et al. 2006) we have categorised juvenile recruits ( $\sim 4$ months old) as fish $<100 \mathrm{~mm}$ standard length (S.L.) for the two catfish and $<75 \mathrm{~mm}$ S.L. for N. erebi and Macquaria sp. B.

All fish caught were identified, counted and the standard lengths in mm of the four most abundant species were measured: P. argenteus, N. hyrtlii, N. erebi and Macquaria sp. B. On the first two sampling dates (April and September 2001), up to 30 randomly selected individuals of each species were measured for standard length at each site, except that $N$. erebi lengths were not recorded in September 2001 due to time constraints. On all sampling occasions thereafter, all individuals up to a maximum of 200 were measured for standard length.

At the time of fish sampling, a single sample of surface water was collected at each site/time and analysed as per standard methods (APHA 1975; EPA 1999) for the following parameters: conductivity, $\mathrm{pH}$, turbidity, hardness, alkalinity, silicates, total ions, total dissolved solids, total carbon, total suspended solids, total $\mathrm{N}$, total $\mathrm{P}, \mathrm{Na}, \mathrm{K}$, Ca, Mg, bicarbonates, carbonates, $\mathrm{Cl}, \mathrm{Fl}$, nitrate and sulphate.

\section{Data analysis}

Prior to statistical analyses, fish data were grouped according to antecedent hydrology and season. Antecedent hydrology was measured in relation to time since flow exceeded $10 \mathrm{~m}^{3} \mathrm{~s}^{-1}$ (recorded at the Currareva gauge), these times being 56, 209, 215 , 67, 12, 40, 184, and 212 days, respectively, on each sampling occasion. Based upon 
these measures there were clearly two antecedent flow groups: short (S) time elapsed (<3mo.) and long (L) time elapsed ( $>6 \mathrm{mo}$.) since flow exceeded $10 \mathrm{~m}^{3} \mathrm{~s}^{-1}$. We used $10 \mathrm{~m}^{3} \mathrm{~s}^{-1}$ as an estimate of the likely lowest flow that physically reaches the study waterholes based upon past observations of stage heights and connectivity among waterholes. The seasonal groups represent time periods with contrasting hydrological and thermal conditions: summer-autumn (SA) = January-April; recent summer flow combined with high water temperatures, autumn-winter (AW) = May to August; recent autumn flows combined with low water temperatures and spring-summer (SS) = September to December; extended time since flow and medium water temperatures. Hence, our flow and seasonal groupings for all sampling occasions are: Time since flow: Short (S) = April 2001, May 2003, March 2004, June 2004; Long (L) = September 2001, October 2002; October 2004 and December 2004. Season: SA = April 2001, March 2004; AW = May 2003, June 2004; SS = September 2001, October 2002, October 2004, December 2004.

Variations in fish species presence/absence and assemblage structure across waterholes and sampling times were analysed using CPUE data based on fyke net catches. CPUE data were also used as a measure of total fish abundance (all species) and the abundance of individual species per waterhole. Species richness for each waterhole was based upon the data collected by both sampling methods. One-way analysis of variance (ANOVA) was used, firstly to test the prediction that antecedent hydrology (fixed factors) influence total fish CPUE and species richness amongst waterholes and across sampling dates, and secondly to test if season (fixed factor) has an influence on CPUE and species richness. It was necessary to use one-way ANOVAs as there were insufficient degrees of freedom to investigate any interaction between antecedent hydrology and season. To meet the assumptions of ANOVA all 
CPUE data were normalised by $\log _{10}(\mathrm{x})$ transformations. Furthermore, these transformations also improved homogeneity of variances among the hydrological and seasonal groups. Statistical significance was recorded at $P \leq 0.05$. Tukeys HSD posthoc tests were used to account for differences in CPUE or species richness among each possible pair of seasonal groups.

In our analysis we also made the assumption that each fish dataset from any one waterhole was independent of the following temporal sample from that waterhole due to the highly variable biological conditions between each subsequent sampling time. To ensure this was statistically sound we also examined residuals (of CPUE and richness) from each waterhole on each sampling occasion using the autocorrelation function in Systat v11.0 to ensure there was no autocorrelation within any one waterhole, confirming that indeed all fish samples were independent from each subsequent temporal sample.

Assemblage patterns were analysed using ordination based upon hybrid nonmetric multi-dimensional scaling (MDS). MDS plots were generated from BrayCurtis similarity matrices produced from $\log _{10}(\mathrm{CPUE}+1)$ and species presence/absence data. One-way analyses of similarities (ANOSIM) based upon the same similarity matrices were used to identify differences in assemblage structure in relation to antecedent hydrology over the period April 2001 to December 2004. ANOSIMS were considered statistically significant at $P \leq 0.05$.

All multivariate analyses were undertaken in the PRIMER version 5 software package (Clarke and Gorley 2001). BIO-ENV function in Primer (Clarke and Warwick 2001) was used to explore the potential influence of water quality parameters on fish assemblages through time. BIO-ENV uses generalised Mantel tests to examine associations between faunal datasets and environmental data 
expressed as Spearman rank correlation coefficients for the association between the two matrices (Clark and Ainsworth 1993). The environmental similarity matrices were based upon normalised Euclidean distance rather than Bray-Curtis similarity, as recommended by Clarke and Warwick (2001).

Associations between individual species and water chemistry parameters were examined using Spearman rank correlation in SPSS. Due to the large number of tests undertaken, significant correlations were accepted at $\mathrm{P}<0.001$ to protect against Type I error (Keppel 1991). All univariate analyses were performed using Systat for Windows 11.00.01 (SSI, 2004).

Fish recruitment patterns of the four common species in the Windorah reach of Cooper Creek were interpreted from size-frequency distributions combined with catch per unit effort data collected using fyke nets and summed across all four waterholes for each sampling occasion. Fyke net data only was used to assess size frequency patterns of the selected species, as these nets have been used successfully in a range of dryland rivers due to them consistently catching the full size-range of fish species, apart from very small juveniles and/or larvae (e.g. Arthington et al. 2005; Balcombe et al. 2005; 2006; 2007). Although the seine net was used to collect additional smallbodied species for species richness counts that may have been missed by the fyke nets, it also served as a verification of presence or absence of juvenile recruits of the four common species. These seines did not on any occasion reveal new recruits not apparent in the fyke nets verifying the use of fyke nets for analysing size-frequency patterns.

\section{Results}

Abundance and species richness 
Approximately 33400 fish were recorded in samples from the four waterholes across eight trips. All 12 fish species recorded in waterholes of the more extensive midCooper Creek catchment by Arthington et al. (2005) were found in the Windorah reach of Cooper Creek throughout this study (Table 1). Over all sampling trips the most abundant species were the plotosid catfishes $P$. argenteus ( $54 \%$ of total catch) and $N$. hyrtlii ( 14\%), the clupeid N. erebi ( 16\%), two terapontids L. unicolor ( $\sim 8 \%)$ and S. barcoo ( 6\%), and the percichthyid Macquaria sp. B ( 2\%) (Table 2). Five of the same six species were also commonly distributed among waterholes and sampling trips, being found in $>87 \%$ of all waterholes across sampling trips except for $S$. barcoo which was less common (67\%).

Temporal trends in total fish catches among the four waterholes in the Windorah reach demonstrate high variability in fish abundance across the eight sampling trips (Table 2). Apart from Glenmurken Waterhole that was actually dry in December 2004, abundance fluctuated from as low as 100 CPUE at Shed Waterhole to as high as 11368 CPUE at Mayfield Waterhole in April 2001. The highest fish abundances (April 2001 and March 2004) were recorded shortly after floods. April 2001 samples were collected two months after a large in-channel flow, which was preceded by the major 2000 flood 12 months earlier, while March 2004 sampling occurred two months after a large flood of similar magnitude to that of the 2000 flood (Fig. 2). Apart from these times of very high fish abundance, the two smaller waterholes (Mayfield and Glenmurken) tended to support higher abundances per unit fishing effort than Murken and Shed waterholes. Shed, the only waterhole situated far out on the Windorah floodplain, supported lower fish abundances than the three waterholes situated within the same river channel (Fig. 1). Shed Waterhole generally receives less flow than the other waterholes and disconnects from the channel network 
more rapidly than they do (Arthington et al. 2005). Although mean CPUE tended to be higher in the S (short) compared to L (long) time since flow group (Fig 3a), the difference was not significant. Seasonal effects on CPUE were, however, significant (Fig. 3b; ANOVA: $F_{2,28}=7.46, P=0.003$ ). Post hoc tests revealed that mean CPUE was higher in SA (January-April; recent summer flow combined with high water temperatures) than both AW- autumn-winter $(P=0.001)$ and SS - spring-summer $(P$ $=0.003)$.

The lowest estimate of native species richness across the eight sampling occasions was five native species at Murken Waterhole in September 2001, with the highest recorded being 11 native species at both Murken and Mayfield waterholes on a number of occasions (Table 2). Mean native species richness was significantly higher in S compared to L time since flow groups (Fig. 3c; ANOVA: $F_{1,29}=4.66, P=$ 0.04). Seasonal effects on richness were also significant (Fig 3d; ANOVA: $F_{2,28}=$ 3.83, $P=0.03$ ). Post hoc tests revealed that of the three possible seasonal comparisons only SA and SS were significantly different $(P=0.03)$ with mean richness in SA being significantly higher than for SS.

\section{Assemblage structure}

Ordination plots revealed that fish assemblage structure based on CPUE data was arrayed in relation to antecedent hydrology with S flow groups in the middle of the plot and the L groups trending towards the upper left corner (Fig. 4a). The difference in structure between the $\mathrm{S}$ and L fish groups was statistically significant (ANOSIM: Global $\mathrm{R}=0.244, \mathrm{P}<0.001)$. In relation to season, fish CPUE formed three groups, with SA forming a relatively tight cluster in the middle to right of the plot, while SS sat towards the top left diagonal, yet overlapped with AW in the bottom left diagonal 
(Fig. 4b). Seasonal groups were significantly different (ANOSIM: Global R =0.29, P $<0.001$ ), and pairwise differences revealed that SA was significantly different to both SS $(\mathrm{P}=0.002)$ and to AW $(\mathrm{P}=0.004)$, while there was no significant difference between SS and AW.

Fish assemblage structure based upon presence/absence data was also differentiated between the two antecedent hydrology groups with the S group tending towards the top left diagonal of the plot and the L groups towards the bottom left diagonal (Fig. 4c). ANOSIM revealed the two flow groups were significantly different (Global $\mathrm{R}=0.17, \mathrm{P}<0.001)$. Fish assemblage presence/absence plots tended to form loose aggregations, with SA grouping the tightest in the top middle of the plot, while SS grouped loosely towards the bottom right diagonal and AW was very loosely aggregated toward the bottom (Fig. 4d). While there was a significant seasonal effect on fish assemblage structure based on presence/absence (ANOSIM: Global $\mathrm{R}=0.16, \mathrm{P}<0.01$ ), the only significantly different pairwise comparison among the three seasonal groups was between SA and SS $(\mathrm{P}=0.02)$.

Associations between fish distribution and water chemistry BIO-ENV revealed that there was no association between any combination of, or any single, water chemistry parameter and fish assemblage CPUE or presence/absence patterns. Spearman rank correlations between individual species and water chemistry parameters did, however, show strong associations. These correlations were all negative and significant at $\mathrm{P}<0.001$ (S. barcoo CPUE and conductivity $\left(\mathrm{r}_{\mathrm{s}}=-0.563\right)$, $\mathrm{pH}\left(\mathrm{r}_{\mathrm{s}}=-0.649\right)$, sulphate $\left(\mathrm{r}_{\mathrm{s}}=-0.638\right)$, . barcoo presence/absence and conductivity $\left(r_{\mathrm{s}}=-0.651\right)$ and sulphate $\left(\mathrm{r}_{\mathrm{s}}=-0.666\right)$, Macquaria sp. B CPUE and conductivity $\left(\mathrm{r}_{\mathrm{s}}\right.$ 
$=-0.66)$ and chloride $\left(\mathrm{r}_{\mathrm{s}}=-0.621\right), P$. argenteus CPUE and $\mathrm{pH}\left(\mathrm{r}_{\mathrm{s}}=-0.666\right)$ and sulphate $\left(\mathrm{r}_{\mathrm{s}}=-0.675\right)$ and L. unicolor CPUE and $\mathrm{pH}\left(\mathrm{r}_{\mathrm{s}}=-0.553\right)$.

\section{Population size structure and recruitment patterns}

Peak abundances of $P$. argenteus juveniles ( $<100 \mathrm{~mm}$ S.L.) coincided with the autumn sampling occasions (e.g. April 2001, May 2003, and March 2004; Fig. 5). Autumn sampling dates all occurred within two months of in-channel or floodplain floods (Fig.

2). The smallest individuals of this species ( $<50 \mathrm{~mm} \mathrm{S.L.)} \mathrm{were} \mathrm{found} \mathrm{in} \mathrm{October}$ 2004, hence it is likely that these individuals were spawned in early spring. These results suggest not only a seasonal spawning response but also enhanced larval/juvenile survival following the occurrence of channel or overbank flows.

Similar to P. argenteus, the other plotosid catfish, $N$. hyrtlii, showed a strong response to flow, with significant increases in juvenile abundance ( $<100 \mathrm{~mm}$ S.L.) following flooding, particularly in April 2001 and March 2004 (Fig. 5). Unlike P. argenteus, there was little evidence of spawning outside the summer periods where the likelihood of flow events are highest.

The presence of juvenile recruits of $N$. erebi ( $<75 \mathrm{~mm}$ S.L.) at all times suggests that this species is not reliant upon flow for recruitment success (Fig. 5). The highest abundances of this species were found in October 2002 and October and December 2004, with high proportions of new recruits contributing to total CPUE at those times. If there is indeed a particular cue influencing spawning and recruitment it would be a factor that was similar across waterholes, such as temperature. While the key periods of juvenile recruitment of $N$. erebi appeared to be spring to summer, juveniles still appeared in autumn samples, but in low abundance (e.g. April 2001 and May 2003). However, the strongest evidence of successful spawning and juvenile 
recruitment occurred during a no-flow period when temperatures were increasing towards spring and summer in the latter part of 2004 (Fig. 5).

Lake Eyre golden perch were clearly able to spawn all year round (Fig. 5) with new juvenile recruits ( $<75 \mathrm{~mm}$ S.L.) recorded on all but one sampling occasion (September 2001). While not dependent upon flow events, it is apparent that the highest juvenile abundances were achieved after there had been some flow, and greater recruitment success was definitely associated with large floods (particularly in March and June 2004), following the large February 2004 flood and a smaller flow pulse that followed in April 2004 (see Fig. 2). 


\section{Discussion}

\section{Hydrological influence on fish assemblages}

Antecedent hydrology linked with seasonal patterns of water temperature had a marked influence on fish assemblage structure, native species richness, abundance and juvenile recruitment patterns in four waterholes at the Windorah reach of Cooper Creek. Ordinations of fish assemblage structure based upon both CPUE and species presence/absence revealed high assemblage variability through time. These variations were significantly influenced by antecedent flow conditions (measured as months elapsed since the last in-channel or flood flow event). Assemblages sampled $<100$ days after medium to large floods (e.g. in April 2001 and March 2004) were very similar and significantly different from those sampled $>100$ days since flow. Elevated abundances of fish following periods of widespread floodplain inundation would reflect the high energy subsidies derived from diverse allochthonous floodplain resources (Arthington et al. 2005; Balcombe et al. 2005; Bunn et al. 2006a; Burford et al. 2008), whereas the marked decreases in fish abundance within the confines of isolated, drying waterholes would be partly a consequence of dependence on autochthonous production (benthic algae), a less diverse food web and declining food resources (Bunn et al. 2003; 2006a,b; Balcombe et al. 2005; Sternberg et al. 2008), as well as loss of habitat and associated water quality and biotic changes (Arthington et al. 2005). These 'boom and bust' patterns of aquatic productivity are a wellestablished feature of Australian dryland river systems such as Cooper Creek (Puckridge et al. 1998; 2000; ; Kingsford et al., 1999; Puckridge 1999) and to a lesser extent, the Warrego River in the upper Murray-Darling Basin (Balcombe et al. 2006). 


\section{Seasonal influence on fish assemblages}

While fish assemblages showed strong responses to channel flow and flooding, the effect of season was equally strong. Fish abundance and species richness were always significantly greater in the SA (summer-autumn) season than either the AW (autumnwinter) or SS (spring-summer) seasons. Furthermore, fish assemblage structure in SA was always significantly differentiated from structure recorded in other seasons. It was not possible to separate the effects of season and flow. However, given that there were always significant differences between S and L flow groups and SA and other seasonal groups for CPUE abundance, species richness and assemblage structure, it is clear that the combinations of high water temperatures and flow events were strong drivers of the patterns found, rather than each factor acting independently. It is the coincidence of channel flow or flooding, linked with seasonal high water temperatures, that drives high pulses of fish production in dryland and other floodplain rivers (Junk et al. 1989; King et al. 2003; Arrington and Winemiller, 2004; Balcombe et al. 2006; 2007; Kingsford et al. 2006).

\section{Variability in fish assemblages among waterholes}

Although high species richness and fish abundance were measured after large floods, the response to antecedent flooding varied among individual species and individual waterholes. For example, in April 2001 there was a strong response to the 2000 flood and to the following 2001 summer flow event, evidenced by the large population of $P$. argenteus at Mayfield but not at nearby Murken waterhole. S. barcoo was also found in very high abundance at Mayfield in April 2001, but in low abundance in this waterhole following the March 2004 flood. N. hyrtlii showed the strongest flood response in Murken waterhole in April 2001. However, in March 2004 this species 
showed a much weaker response to flooding, while $P$. argenteus had a much stronger response, becoming the most abundant species. These variations could conceivably be explained by past trajectories of temporal change and differences in fish assemblage structure in each waterhole at the start of our study, April 2001 (see Arthington et al. 2005). Such differences would be due to a combination of the amount of floodplain habitat available during floodplain inundation, and variable patterns and rates of migration off floodplains the previous summer (2000-2001), as well as differential immigration-emigration patterns and rates among waterholes while they were still connected by flow. For example, Arthington et al. (2005) found a strong positive correlation between total and effective floodplain width and the abundance of $P$. argenteus and Macquaria sp. B in waterholes after floodplain recession, and also demonstrated the influence of waterhole connectivity on fish assemblage structure in waterholes. Density-dependent responses of fish populations to available resources in floodplain and waterhole habitats (Junk et al. 1989; Welcomme and Halls 2004; Balcombe et al. 2005) would also be likely to play a significant role in structuring the assemblages that colonize and settle in individual waterholes after floods recede. These responses would in turn influence the trajectories of change in each assemblage as a function of increasing waterhole isolation and desiccation, as shown over the 2001 dry season in Cooper Creek (Arthington et al. 2005). These waterhole trajectories would also be influenced by natural processes of competition and predation and hence, survival, which would be reflected in the relative success of juvenile recruitment. 


\section{Individual variability among fish species}

One interesting aspect of these "boom and bust" abundance patterns is the speciesspecific change in abundance through time. For example, S. barcoo achieved its highest abundances in the three in-channel waterholes soon after the two largest floods (2000 and 2004) during the study period, thereafter declining rapidly to very low abundances, or being absent on all other sampling occasions. The presence and abundance of this species in a waterhole was negatively correlated with conductivity and sulphate concentrations, whereas its abundance was also negatively correlated with $\mathrm{pH}$. Hence, S. barcoo may be sensitive to fluctuations in some aspects of water quality. It is also possible that $S$. barcoo is sensitive to crowding and stress resulting from waterholes shrinking as they dry down, when the decreasing water quality itself reflects the drying phase (Hamilton et al. 2005; Kingsford et al. 2006). A high incidence of lesions ( $50 \%$ of all fish) was noted for this species in March 2004, suggesting susceptibility to fungal infection under crowded conditions.

$N$. hyrtlii tended to decrease in most waterholes following the episodes of very high abundance recorded in April 2001 and to a lesser extent in October 2002. There appeared to be some recovery following the 2004 flood, yet this catfish declined thereafter. In contrast, $N$. erebi tended to increase in abundance over time since the last flow event, actually becoming the dominant species (in abundance) by June and through October and December 2004. Furthermore, Shed waterhole, which consistently exhibited low total CPUE over most sampling occasions, had by far the highest fish abundance in December 2004, mostly due to the high numbers of $N$. erebi. Hence, even after many months of no flow and pressure on declining habitat and food resources, some fish species recover and flourish in particular waterholes. 
Floodplain setting, connectivity, waterhole morphology, habitat structure and associated abiotic/biotic pressures partly explain these variations in fish abundance from one waterhole to another during dry periods (Arthington et al. 2005). Overall, these different patterns of species dominance reflect the highly dynamic nature of fish assemblages in Cooper Creek due to the interplay of factors such as colonization and extinction, competition, predation and changes to habitat structure and food resources among waterholes (Magoulick and Kobza, 2003; Arthington et al. 2005; Balcombe et al. 2005).

\section{Recruitment patterns of fish species}

Given that patterns of fish species presence/absence, assemblage structure and abundance were strongly linked to the time elapsed since the last antecedent flow, it was no surprise that recruitment patterns of fish were also strongly influenced by flow, yet responses differed considerably among the four common species. The catfish, $P$. argenteus, had very strong juvenile recruitment periods linked to all summer-autumn flows, suggesting a peak spawning season between December and March. However, the appearance of very small individuals in October 2004 suggests that the timing and duration of the spawning period may vary, under particular conditions that are not yet understood. These conditions may include rising temperature from winter through to mid-summer and hydrological changes, such as drying events and floods or flow-pulses throughout the spring to autumn season. That this species appeared to spawn in the absence of flow suggests that flow and associated conditions are not essential to achieve juvenile recruitment. However, the high abundances recorded following channel flows and flooding (the "boom" response) suggest that the occurrence of backwater and floodplain inundation probably enhance larval and juvenile survival, and that an increase in flooded habitats 
is an important feature enabling $P$. argenteus to build up sufficient numbers for at least some healthy individuals to persist through periods when channel flows are low or waterholes are drying down (the "bust” period). Given that larvae of this species were found on the Windorah floodplain in both February/March 2000 and January 2004 (Balcombe et al. 2007), our findings certainly suggest that recruitment success of $P$. argenteus is strongly linked with flooding.

There was no evidence of juvenile $N$. hyrtlii recruitment in Cooper Creek in the absence of flow. It appears that $N$. hyrtlii is an obligate flood spawner, which reinforces the findings of Orr and Millward (1984) and Pusey et al. (2004) who reported spawning on rising water levels at the start of the wet season in rivers of northern Australia. Furthermore, spawning is likely to be restricted to the summer months, suggesting that the spawning cue would be a combination of increase in temperature, probably above $25^{\circ} \mathrm{C}$ (Pusey et al. 2004) and the occurrence of flow. In the Warrego River, $N$. hyrtlii also revealed a pattern of obligate flood spawning when both flooding and high temperatures were synchronised (Balcombe et al. 2006). Larvae of $N$. hyrtlii were found on the floodplain at Windorah during the January 2004 flood (Balcombe et al. 2007), providing further evidence of the importance of floodplain habitats, rich food resources and high temperatures to the recruitment success of $N$. hyrtlii.

Both N. erebi and Macquaria sp. B appeared to have the most flexible recruitment patterns of the four species studied in Cooper Creek. N. erebi showed similar flexibility of response to flow conditions in the Warrego River, a tributary of the Murray-Darling with a variable flow regime (Balcombe et al. 2006). Macquaria ambigua (closely related to Macquaria sp. B) also exhibited flexible recruitment patterns in the Warrego River. In the present study, there was only one sampling 
occasion, October 2001, when there was no obvious recruitment of juveniles of Macquaria sp. B (Fig. 5). This lack of spawning or low recruitment success was more likely to reflect the fact that the whole fish assemblage was in a state of severe population decline by October 2001 (Arthington et al. 2005) as drying waterholes reached their carrying capacity after the "boom" of post-flood recruitment in the summer of 2001, rather than a reflection of the breeding biology of Maquaria sp. B. In addition to spawning in waterholes, larvae of $N$. erebi and Macquaria sp. B were recorded on the floodplain at Windorah during the summer floods of 2000 and 2004 (Balcombe et al. 2007). The general prevalence of juveniles of Macquaria sp. B throughout the year during our study period is also in general agreement with the observations of Mallen-Cooper and Stuart (2003), who suggested that the closely related M. ambigua is not an obligate flood spawner. In the Cooper Creek system, however, Macquaria sp. B has a much more protracted spawning season than $M$. ambigua in the Murray-Darling river system, which could be due to the higher mean monthly water temperatures in this arid region of Australia compared to more southern areas.

The only period when $N$. erebi did not appear to achieve any recent juvenile recruitment was March 2004, with most individuals being either immature or mature fish. However, sampling on the Windorah floodplain in January 2004 produced many late stage larvae and juveniles, suggesting successful summer spawning by this species (Balcombe et al. 2007). Rather than no recruitment it is probable that these fish had grown at a much greater rate than would be expected had they spent most of their post-larval life in a waterhole rather than on the warmer, more productive floodplain. The floodplain is a resource-rich environment for this species (Balcombe et al. 2005) and floodplain water temperatures were generally high (between 26 and 
$39^{0} \mathrm{C}$ ), which would have accelerated fish growth. Similar to the pattern for Macquaria sp. B, N. erebi in Cooper Creek has a more flexible and prolonged spawning season than further south (Puckridge and Walker 1990). In Cooper Creek N. erebi appears able to spawn most of the year, in flood, flow and drying conditions, making it highly adapted to the unpredictable hydrological environment it occupies. Unlike the other three common species, however, $N$. erebi did not exhibit increased numbers (particularly juveniles) after floods, suggesting that the life-cycle of these fish is not dependent upon channel flow or flooding (as also noted by Pusey et al. 2004).

\section{Ecology of Cooper Creek fish}

The four fish species studied here would fit into the eupotamonic phytophilic guild of Welcomme et al. (2006b), all being able to migrate both laterally between channels and floodplains, and longitudinally along wetted channels and/or down the floodplain under flow or flood conditions (Pusey et al. 2004; Balcombe et al. 2007). As such they would be sensitive to any changes in hydrology and/or habitat connectivity that prevents either in-stream movement and/or floodplain access. At present, flow in Cooper Creek is not regulated by dams and weirs. Furthermore, waterhole depths and volumes are minimally affected by domestic/rural water abstraction and there are few artificial impediments to free movements of fish within river channels and to and from floodplains during floods.

As a free-flowing arid-zone floodplain river, Cooper Creek provides an ideal system for exploring the influence of flow variability (sensu Poff et al. 1997) and extreme flow events (floods and extended dry spells) on the ecology of fishes. This study along with the floodplain studies of Balcombe et al. (2007) has found evidence of flexible seasonal spawning times and opportunistic responses to flow/flooding 
coupled with the capacity for larvae and juveniles to exploit the resources of inundated backwater and floodplain habitats during channel flows, and especially during occasional large floods. Our results reinforce observations on these common species in other parts of their range (Pusey et al. 2004). This flexibility of response to flow events and related conditions appears to be an important trait of the most successful fish species in Cooper Creek and helps to explain the prominent 'boom and bust' patterns of fish production in this hydrologically-variable floodplain river system. These temporal population fluctuations and opportunistic recruitment strategies have many parallels in fishes of the world's arid-zone rivers (Skelton, 1986; Medeiros and Maltchik 2001a, b; Kingsford et al. 2006; Zeug and Winemiller 2008). Arid-zone rivers and their fish assemblages provide an example of the ecological importance of extreme natural flow variability and the spatial and temporal patterns of flooding, dry spells and the flow conditions in between (Puckridge et al. 1998; Bunn et al. 2006b; Kingsford 2006). It is imperative that we understand the ecological importance of this natural variability in the lives of fishes and other aridzone species before too many more dryland rivers and ecosystems in desert landscapes become threatened by human water demands and climate change (Postel 1999; Maltchik and Medeiros 2006; Kingsford 2006; Wishart 2006). Cooper Creek and its freshwater biota including fish may serve as a model for understanding 'boom and bust' ecological processes of broad relevance to many arid zone/dryland floodplain rivers.

\section{Acknowledgements}


The authors would like to thank the various Dryland Refugia Project team members and volunteers who provided field support, and Sandy Kidd and David Smith for providing access to waterholes on their properties. Thanks also to Kim Markwell for summarising hydrology data provided by the Queensland Department of Natural Resources and Mines. We also appreciate the constructive comments provided by two anonymous reviewers. Our research was conducted under Queensland Fisheries Permit PRM00157K and Griffith University Animal Experimentation Ethics permit $\mathrm{AES} / 03 / 02$. 


\section{References}

APHA (1975). 'Standard Methods for the Examination of water and Wastewater.' $14^{\text {th }}$ edn. (American Public Health Association: Washington, DC.)

Arrington, D. A., and Winemiller, K. O. (2004). Organization and maintenance of fish diversity in shallow waters of tropical floodplain rivers. In 'Proceedings of the Second International Symposium on the Management of Large Rivers for Fisheries.’ (Eds R. L. Welcomme R. L. and T. Petr.) Volume II, pp. 25-36. RAP Publication 2004/17. (FAO Regional Office for Asia and the Pacific: Bangkok, Thailand.)

Arthington, A. H., Balcombe, S. R., Wilson, G. A., Thoms, M. C., and Marshall, J. (2005). Spatial and temporal variation in fish assemblage structure in isolated waterholes during the 2001 dry season of an arid-zone river, Cooper Creek, Australia. Marine and Freshwater Research 56, 25-35.

Balcombe, S. R., Arthington, A. H., Foster, N. D., Thoms, M. C., Wilson, G. G., et al. (2006). Fish assemblages of an Australian dryland river: abundance, assemblage structure and recruitment patterns in the Warrego River, MurrayDarling Basin. Marine and Freshwater Research 57, 619-633.

Balcombe, S. R., Bunn, S. E., Arthington, A. H., Fawcett, J. H., McKenzie-Smith, F. J., et al. (2007). Fish larvae, growth and biomass relationships in an Australian arid zone river: links between floodplains and waterholes. Freshwater Biology 52, 2385-2398.

Balcombe, S. R., Bunn, S. E., McKenzie-Smith, F. J., and Davies, P. E. (2005). Variability of fish diets between dry and flood periods in an arid zone floodplain river. Journal of Fish Biology 67, 1552-1567. 
Bunn, S. E., Balcombe, S. R., Davies, P. M., Fellows, C. S., and McKenzie-Smith, F. J. (2006a). Aquatic productivity and food webs of desert river ecosystems. In 'Ecology of Desert Rivers.' (Ed. R. T. Kingsford.) pp. 76-99. (Cambridge University Press: Melbourne.)

Bunn, S. E., Davies, P. M., and Winning, M. (2003). Sources of organic carbon supporting the food web of an arid zone floodplain river. Freshwater Biology 49, 619-635.

Bunn, S. E., Thoms, M. C., Hamilton, S. K., and Capon, S. J. (2006b). Flow variability in dryland rivers: boom, bust and the bits in between. River Research and Applications 22, 179-186.

Burford, M.A., Cook, A.J., Fellows, C.S., Balcombe, S.R., and Bunn, S.E. (2008). Sources of carbon fuelling production in an arid floodplain river. Marine and Freshwater Research 59, 224-234.

Clark, K. R., and Gorley, R. N. (2001). 'Primer v5: User Manual/Tutorial.’ (PRIMERE Ltd: Plymouth.)

Clarke, K. R., and Warwick, R. M. (2001). 'Change in Marine Communities: An Approach to Statistical Analysis and Interpretation.' 2nd edn. (PRIMER-E Ltd: Plymouth.)

Cushing, D. H. (1990). Plankton production and year-class strength in fish populations: an update of the match/mismatch hypothesis. Advances in Marine Biology 26, 249-293.

EPA (1999). 'Water Quality Sampling Manual (Qld).’ $3^{\text {rd }}$ edn. (Queensland Environmental Protection Agency: Brisbane.) 
Hamilton, S. K., Bunn, S. E., Thoms, M. C., and Marshall, J. C. (2005). Persistence of aquatic refugia between flow pulses in a dryland river system (Cooper Creek, Australia). Limnology and Oceanography 50, 743-754.

Humphries, P., King, A. J., and Koehn, J. D. (1999). Fish, flows and floodplains: links between freshwater fishes and their environment in the Murray-Darling River system, Australia. Environmental Biology of Fishes 56, 129-51.

Jackson, D. A., Peres-Neto, P. R., and Olden, J. D. (2001). What controls who is where in freshwater fish communities - the roles of biotic, abiotic and spatial factors. Canadian Journal of Fisheries and Aquatic Sciences 58, 157-70.

Junk, W. J., Bayley, P. B., and Sparks, R. E. (1989). The flood pulse concept in riverfloodplain systems. In 'Proceedings of the International Large River Symposium.’ (Ed. D.P. Dodge.) pp. 110-127. Canadian Special Publication Fisheries and Aquatic Sciences 106.

Keppel, G. (1991). ‘Design and Analysis: a Researcher’s Handbook’. (Prentice-Hall: New Jersey, USA.)

King, A. J. (2004). Ontogenetic patterns of habitat use by fishes within the main channel of an Australian floodplain river. Journal of Fish Biology 65, 15821603.

King, A. J., Humphries, P., and Lake, P. S. (2003). Fish recruitment on floodplains: the roles of patterns of flooding and life history characteristics. Canadian Journal of Fisheries and Aquatic Sciences 60, 773-86.

Kingsford, R.T. (2006). Changing desert rivers. In 'Ecology of Desert Rivers.' (Ed. R. T. Kingsford.) pp. 336-345. (Cambridge University Press: Melbourne.) 
Kingsford, R. T., Curtin, A. L., and Porter, J. L. (1999). Water flows on Cooper Creek determine 'boom' and 'bust' periods for waterbirds of the Paroo and Warrego Rivers. Biological Conservation 88, 231-48.

Kingsford, R.T., Georges, A., and Unmack, P.J. (2006). Vertebrates of desert rivers: meeting the challenges of temporal and spatial unpredictability. In 'Ecology of Desert Rivers.' (Ed. R. T. Kingsford.) pp. 154-200. (Cambridge University Press: Melbourne.)

Knighton, A. D., and Nanson, G. C. (1994). Waterholes and their significance in the anastomosing channel system of Cooper Creek, Australia. Geomorphology $\mathbf{9}$, $311-24$.

Knighton, A. D., and Nanson, G. C. (2001). An event based approach to the hydrology of arid zone rivers in the Channel Country of Australia. Journal of Hydrology 254, 102-123.

Magoulick, D. D., and Kobza, R. M. (2003). The role of refugia for fishes during drought: a review and synthesis. Freshwater Biology 48, 1186-98.

Mallen-Cooper, M., and Stewart, I. (2003). Age, growth and non-flood recruitment of two potamodromous fishes in a large semi-arid temperate river system. River Research and Applications 19, 697-719.

Maltchik, L., and Medeiros, E. S. F. (2006). Conservation importance of semi-arid streams in north-eastern Brazil: implications of hydrological disturbance and species diversity. Aquatic Conservation: Marine and Freshwater Ecosystems 16, 665-677.

Marshall, J. C., Sheldon, F., Thoms, M. C., and Choy, S. (2006). The macroinvertebrate fauna of an Australian dryland river: spatial and temporal 
patterns and environmental relationships. Marine and Freshwater Research $57,61-74$.

Medeiros, E. S. F., and Maltchik, L. (2001a). Fish assemblage stability in an intermittently flowing stream from the Brazilian semiarid region. Austral Ecology 26, 156-164.

Medeiros, E. S. F., and Maltchik, L. (2001b). Effects of flood and drought on diversity and stability of fishes in a temporary river from the Brazilian semiarid region. Iheringia 90, 157-166.

Middleton, N.J., and Thomas, D.S.G. (1997). 'World Atlas of Desertification.' (UNEP/Edward Arnold: London.)

Milton, D. A., and Arthington, A. H. (1984). Reproductive strategy and growth of the crimson-spotted rainbowfish, Melanotaenia splendida fluviatilis (Castelnau) (Pisces: Melanotaeniidae) in south-eastern Queensland. Australian Journal of Marine and Freshwater Research 35, 75-83.

Milton, D. A., and Arthington, A. H. (1985). Reproductive strategy and growth of the Australian smelt, Retropinna semoni (Weber) (Pisces: Retropinnidae), and the olive perchlet, Ambassis nigripinnis (De Vis) (Pisces: Ambassidae) in Brisbane, south-eastern Queensland. Australian Journal of Marine and Freshwater Research 36, 329-341.

Morton, S. J., Short, J., and Baker, R. D. (1995). Refugia for biological diversity in arid and semi-arid Australia. Biodiversity Series, Paper No. 4 (Department of Environment, Sport and Territories: Canberra.)

Musyl, M. K., and Keenan, C. P. (1992). Population genetics and zoogeography of Australian freshwater Golden Perch, Macquaria ambigua (Richardson 1845) 
(Teleostei: Percichthyidae), and electrophoretic identification of a new species from the Lake Eyre Basin. Australian Journal of Marine and Freshwater Research 43, 1585-1601.

Orr, T. M., and Millward, N. E. (1984). Reproduction and development of Neosilurus ater (Perugia) and Neosilurus hyrtlii Steindachner (Teleostei: Plotosidae) in a tropical Queensland stream. Australian Journal of Marine and Freshwater Research 35, 197-195.

Poff, N. L., Allan, J. D., Bain, M. B., Karr, J. R., Prestegaard, K. L. et al. (1997). The natural flow regime - a paradigm for river conservation and restoration. BioScience 47, 769-84.

Postel, S. (1999). Pillar of Sand. Can the Irrigation Miracle Last? (W.W. Norton and Company: New York.)

Puckridge, J. T. (1999). The role of hydrology in the ecology of Cooper Creek, Central Australia: implications for the flood pulse concept. PhD Thesis (The University of Adelaide: Adelaide, South Australia.)

Puckridge, J. T., Sheldon, F., Walker, K. F., and Boulton, A. J. (1998). Flow variability and the ecology of large rivers. Marine and Freshwater Research 49, 55-72.

Puckridge, J. T., and Walker, K. F. (1990). Reproductive biology and larval development of a gizzard shad, Nematalosa erebi (Gunther) (Dorostomatinae: Teleosti), in the River Murray, South Australia. Australian Journal of Marine and Freshwater Research 41, 695-712.

Puckridge, J. T., Walker, K. F., and Costelloe, J. F. (2000). Hydrological persistence and the ecology of dryland rivers. Regulated Rivers: Research and Management 16, 385-402. 
Pusey, B. J., Arthington, A. H., Bird, J. R., and Close, P. G. (2001). Reproduction in three species of rainbowfish (Melanotaeniidae) from rainforest streams in northern Queensland, Australia. Ecology of Freshwater Fish 10, 75-87.

Pusey, B. J., Close, P. G., Arthington, A. H., and Bird, J. (2002). Larval fishes in rainforest streams: recruitment and microhabitat use. Proceedings of the Royal Society of Queensland 110, 27-46.

Pusey, B. J., Kennard, M. J., and Arthington, A. H. (2004). 'Freshwater Fishes of North-eastern Australia.' (CSIRO Publishing: Collingwood, Victoria, Australia.)

Rodriguez, M. A., and Lewis, W. M. Jr. (1997). Structure of fish assemblages along environmental gradients in floodplain lakes of the Orinoco River. Ecological Monographs 67, 109-28.

Skelton, P. H. (1986). Fish of the Orange-Vaal system. Monographiae Biologicae 60, 143-161.

Sternberg, D., Balcombe, S., Marshall, J., and Lobegeiger, J. (2008). Food resource variability in an Australian dryland river: evidence from the diet of two generalist native fish species. Marine and Freshwater Research 59, 137-144.

Systat Software, Inc. (SSI), (2004). 'Systat ${ }^{\circledR}$ for Windows ${ }^{\circledR}$.' (Richmond: CA).

Tejerina-Garro, F. L., Fortin, R., and Rodriguez, M. A. (1998). Fish community structure in relation to environmental variation in floodplain lakes of the Araguaia River, Amazon Basin. Environmental Biology of Fishes 51, 399-410.

Walker, K. F., Sheldon, F., and Puckridge, J. T. (1995). An ecological perspective on dryland river ecosystems. Regulated Rivers: Research and Management 11, 85-104. 
Welcomme, R. L. (2001). 'Inland Fisheries Ecology and Management.’ (Fishing News Books, Blackwell Science Ltd: Oxford, United Kingdom.)

Welcomme, R. L., and Halls, A. (2004). Dependence of tropical river fisheries on flow. In 'Proceedings of the Second International Symposium on the Management of Large Rivers for Fisheries.' (Eds R. L. Welcomme and T. Petr) Volume II, pp. 267-284. RAP Publication 2004/17. (FAO Regional Office for Asia and the Pacific: Bangkok, Thailand.)

Welcomme, R. L., Bene, 'C., Brown, C. A., Arthington, A., Dugan, P., et al. (2006a). Predicting the water requirements of river fisheries. In 'Wetlands and Natural Resource Management.’ (Eds J. T. A. Verhoeven, B. Beltman, R. Bobbink, D. F. Whigham) pp .123-154. (Springer-Verlag: Berlin, Heidelberg).

Welcomme, R. L., Winemiller, K. O., and Cowx, I. G. (2006b). Fish environmental guilds as a tool for assessment of ecological condition of rivers. River Research and Applications 22, 377-396.

Wishart, M.J. (2006). Water scarcity: politics, populations and the ecology of desert rivers. In 'Ecology of Desert Rivers.’ (Ed. R. T. Kingsford.) pp. 315-335. (Cambridge University Press: Melbourne.)

Zeug, S.C. and Winemiller, K.O. (2008). Relationships between hydrology, spatial heterogeneity and fish recruitment dynamics in a temperate floodplain river. River Research and Applications 24, 90-102. 


\section{Tables}

Table 1. Fish distribution and size range for all species collected from four waterholes in the Windorah reach of Cooper Creek during eight sampling trips in 2001-2004.

\begin{tabular}{|c|c|c|}
\hline Family/species & Common name & $\begin{array}{l}\text { Size range } \\
\text { (standard length } \\
\text { in } \mathrm{mm} \text { ) }\end{array}$ \\
\hline \multicolumn{3}{|l|}{ Indigenous species } \\
\hline \multicolumn{3}{|l|}{ Chandidae } \\
\hline \multicolumn{3}{|l|}{ Clupeidae } \\
\hline \multicolumn{3}{|l|}{ Gobiidae } \\
\hline \multicolumn{3}{|l|}{ Melanotaeniidae } \\
\hline \multicolumn{3}{|l|}{ Percichthyidae } \\
\hline $\begin{array}{l}\text { Macquaria sp. B (after Musyl and Keenan, } \\
\text { 1992) }\end{array}$ & $\begin{array}{l}\text { Lake Eyre golden } \\
\text { perch }\end{array}$ & 20-398 \\
\hline \multicolumn{3}{|l|}{ Plotosidae } \\
\hline \multicolumn{3}{|l|}{ 1998) } \\
\hline Neosilurus hyrtlii Steindachner, 1867 & Hyrtl's tandan & $53-350$ \\
\hline Porochilus argenteus (Zeitz, 1896) & silver tandan & 49-199 \\
\hline \multicolumn{3}{|l|}{ Retropinnidae } \\
\hline Retropinna semoni (Weber, 1895) & Australian smelt & $20-65$ \\
\hline \multicolumn{3}{|l|}{ Terapontidae } \\
\hline Bidyanus welchi (McCulloch and Waite, 1917) & Welch's grunter & $91-263$ \\
\hline Leiopotherapon unicolor (Günther, 1859) & spangled perch & $16-193$ \\
\hline Scortum barcoo (McCulloch and Waite, 1917) & Barcoo grunter & $19-227$ \\
\hline \multicolumn{3}{|l|}{ Alien species } \\
\hline \multicolumn{3}{|l|}{ Cyprinidae } \\
\hline \multicolumn{3}{|l|}{ Poeciliidae } \\
\hline Gambusia holbrooki (Girard, 1859) & mosquitofish & $8-43$ \\
\hline
\end{tabular}


Table 2. Catch per unit effort data for fyke net catches in four Cooper Creek waterholes on eight sampling occasions between April 2001 and December 2004. Sites: MW=Murken, MF=Mayfield, GM=Glenmurken, SH=Shed. Numbers refer to sampling dates: 1=April 2001, 2=September 2001, $3=$ October 2002, 4=May 2003, 5=March 2004, 6=June 2004, 7=October 2004, 8=December 2004. *Denotes additional presence of a species captured from seine net.

\begin{tabular}{|c|c|c|c|c|c|c|c|c|c|c|c|c|c|c|c|c|}
\hline Species & MW1 & MW2 & MW3 & MW4 & MW5 & MW6 & MW7 & MW8 & MF1 & MF2 & MF3 & MF4 & MF5 & MF6 & MF7 & MF8 \\
\hline Ambassis sp. & 2 & 0 & 0 & 0 & 0 & 0 & 0 & 1 & 2 & 4 & 2 & 0 & $* 0$ & 3 & 5 & 1 \\
\hline N. erebi & 11 & 0 & 3 & 115 & 145 & 32 & 116 & 192 & 28 & 1 & 494 & 87 & 83 & 139 & 382 & 37 \\
\hline Hypseleotris spp. & 0 & 0 & 0 & $*_{0}$ & 0 & $*_{0}$ & $* 0$ & $*_{0}$ & $*_{0}$ & 3 & 6 & $* 0$ & 0 & 0 & 0 & $*_{0}$ \\
\hline M. splendida tatei & 2 & 0 & 0 & $*_{0}$ & $*_{0}$ & 2 & 0 & 0 & 3 & 0 & 0 & 0 & $* 0$ & 1 & 2 & 9 \\
\hline Macquaria sp. & 23 & 0 & 13 & 7 & 66 & 17 & 3 & 8 & 37 & 1 & 0 & 22 & 32 & 7 & 10 & 5 \\
\hline N. cooperensis & 4 & 0 & 4 & 0 & 5 & 1 & $* 0$ & 0 & 4 & 0 & 2 & 0 & 2 & 0 & 0 & 1 \\
\hline N. hyrtlii & 2872 & 63 & 137 & 7 & 311 & $*_{0}$ & $* 0$ & 9 & 152 & 2 & 255 & 2 & 129 & 14 & 27 & 20 \\
\hline$P$. argenteus & 428 & 166 & 49 & 28 & 3149 & 49 & 9 & 28 & 8898 & 219 & 518 & 808 & 531 & 41 & 5 & 4 \\
\hline R. semoni & 2 & $*_{0}$ & 2 & 0 & 0 & 0 & $*_{0}$ & $*_{0}$ & 0 & 0 & 0 & 1 & $* 0$ & 0 & 2 & $*_{0}$ \\
\hline B. welchi & 4 & 0 & 0 & 2 & 0 & 2 & 0 & 0 & 1 & 0 & 0 & 0 & 9 & $*_{0}$ & 0 & 1 \\
\hline L. unicolor & 326 & 33 & 6 & 0 & 208 & 7 & 6 & 2 & 405 & 0 & 4 & 0 & 279 & 5 & 15 & 4 \\
\hline S. barcoo & 77 & 5 & 0 & 0 & 77 & 5 & $*_{0}$ & $*_{0}$ & 1825 & 0 & 0 & 4 & 47 & $*_{0}$ & 0 & 0 \\
\hline C. auratus & 4 & 3 & 0 & 0 & 0 & 0 & 0 & 0 & 13 & 1 & 2 & 0 & 0 & 0 & 0 & 0 \\
\hline G. holbrooki & 2 & 0 & 0 & 0 & 0 & $*_{0}$ & 0 & 0 & 0 & 0 & 0 & 0 & $* 0$ & 0 & 0 & $*_{0}$ \\
\hline Total CPUE & 3757 & 270 & 214 & 159 & 3961 & 115 & 134 & 240 & 11368 & 231 & 1283 & 924 & 1112 & 210 & 448 & 82 \\
\hline \multirow[t]{2}{*}{ Total native species } & 11 & 5 & 7 & 7 & 8 & 10 & 8 & 8 & 11 & 6 & 7 & 7 & 11 & 9 & 8 & 11 \\
\hline & GM1 & GM2 & GM3 & GM4 & GM5 & GM6 & GM7 & GM8 & SH1 & SH2 & SH3 & $\mathrm{SH} 4$ & SH5 & SH6 & SH7 & SH8 \\
\hline Ambassis sp. & 8 & 26 & 2 & 1 & 0 & 0 & $*_{0}$ & 0 & 0 & 0 & 0 & 0 & 0 & 0 & 0 & 0 \\
\hline N. erebi & 63 & 231 & 54 & 174 & 81 & 92 & 264 & 0 & 44 & 4 & 31 & 101 & 94 & 116 & 313 & 1812 \\
\hline Hypseleotris spp. & 0 & 59 & $*_{0}$ & $*_{0}$ & 0 & $*_{0}$ & 0 & 0 & $*_{0}$ & 1 & $*_{0}$ & 1 & $*_{0}$ & 0 & $*_{0}$ & $*_{0}$ \\
\hline M. splendida tatei & 0 & $*_{0}$ & $* 0$ & $*_{0}$ & $*_{0}$ & 7 & 59 & 0 & 1 & 0 & 0 & 0 & 0 & 2 & 2 & 9 \\
\hline Macquaria sp. & 3 & 3 & 5 & 27 & 36 & 30 & 2 & 0 & 10 & 5 & 4 & 82 & 28 & 10 & 19 & 4 \\
\hline N. cooperensis & 0 & 0 & 0 & 0 & 0 & 1 & 0 & 0 & 0 & 0 & 0 & 0 & 1 & 0 & 0 & 0 \\
\hline
\end{tabular}




\begin{tabular}{|c|c|c|c|c|c|c|c|c|c|c|c|c|c|c|c|c|}
\hline N. hyrtlii & 38 & 0 & 45 & $* 0$ & 105 & 2 & 28 & 0 & 287 & 11 & 13 & $* 0$ & 4 & 1 & 6 & 2 \\
\hline P. argenteus & 738 & 689 & 42 & 778 & 303 & 238 & 25 & 0 & 38 & 33 & 6 & 20 & 39 & 9 & 4 & 4 \\
\hline R. semoni & 0 & 0 & 0 & 2 & 2 & 0 & 0 & 0 & $* 0$ & 1 & 5 & $* 0$ & 0 & 1 & 16 & $* C$ \\
\hline B. welchi & 0 & 0 & 0 & 0 & 2 & 0 & 0 & 0 & 0 & 0 & 0 & 0 & 1 & 0 & 0 & $c$ \\
\hline L. unicolor & 207 & 20 & 15 & 0 & 855 & 29 & 52 & 0 & 104 & 11 & 5 & 2 & 10 & 1 & $*_{0}$ & 5 \\
\hline S. barcoo & 48 & $* 0$ & 0 & 0 & 12 & 3 & 0 & 0 & 1 & 0 & 0 & 1 & 0 & 0 & $* 0$ & $c$ \\
\hline C. auratus & 12 & $* 0$ & 2 & $* 0$ & 0 & 0 & 2 & 0 & 0 & 1 & 0 & 0 & 0 & 0 & 0 & 0 \\
\hline G. holbrooki & 0 & 0 & 0 & 0 & 0 & 0 & 0 & 0 & 0 & 0 & 0 & 0 & 0 & 0 & 0 & 0 \\
\hline Total CPUE & 117 & 1028 & 165 & 982 & 1396 & 402 & 432 & 0 & 485 & 67 & 64 & 207 & 177 & 140 & 360 & 1836 \\
\hline Total native species & 7 & 8 & 8 & 8 & 9 & 9 & 7 & 0 & 9 & 7 & 7 & 8 & 8 & 7 & 9 & $\varepsilon$ \\
\hline
\end{tabular}




\section{LIST OF FIGURES}

Figure 1. The Cooper Creek catchment and the configuration of the four waterholes sampled in the Windorah reach. Currareva Waterhole is listed as a point of reference, but is not a study waterhole.

Figure 2. Daily discharge of the Thomson and Barcoo rivers (combined) from December 1999 to December 2004 and daily maximum and minimum air temperatures at Windorah between January 2001 and December 2004. Arrows indicate fish sampling occasions. Note the split discharge scale for clarity between low and high flows.

Figure 3. Mean ( \pm 1.S.D.) of $\log _{10}$ (CPUE) and species richness in relation to A. and B. (time since flow categories) and C. and D. (seasonal categories).

Figure 4. Non-metric multidimensional scaling plots of fish assemblage structure based on $\log _{10}(x+1)$ transformed catch per unit effort (CPUE) data ( $a$ and $\left.b\right)$, and presence/absence of species (c and d), for eight sampling occasions at the four Windorah waterholes. Note: (a) and (c) show sites and sampling times grouped according to time since flow categories, where closed squares $=$ Short $(\mathrm{S})$ time since flow and open squares $=$ Long $(\mathrm{L})$ time since flow. (b) and (d) show sites and sampling times grouped according to seasonal categories, where open squares $=$ spring-summer (SS), closed squares = autumn-winter (AW) and grey closed diamonds = summer-autumn (SA). Codes aligned with symbols refer to waterhole and sampling occasion: A = Murken Waterhole, $\mathrm{B}=$ Shed Waterhole, $\mathrm{C}=$ Glenkurken Waterhole and D= Mayfield Waterhole, 1 = April 2001, 2 = September 2001, 3 = October 2002, $4=$ May 2003, $5=$ March 2004, 6 = June 2004, 7 = October 2004 and 8 = December 2004.

Figure 5. Length-frequency plots for Porochilus argenteus, Neosilurus argenteus, Nematalosa erebi and Macquaria sp. B from four waterholes within the Windorah reach, Cooper Creek, collected on eight sampling occasions. Total CPUE for each species on each sampling date appears in top right corner of each individual plot. Numbers above individual bars indicate actual frequency where bar has been reduced for ease of presentation. * indicates that $N$. erebi lengths were not measured on this sampling occasion due to time constraints. 


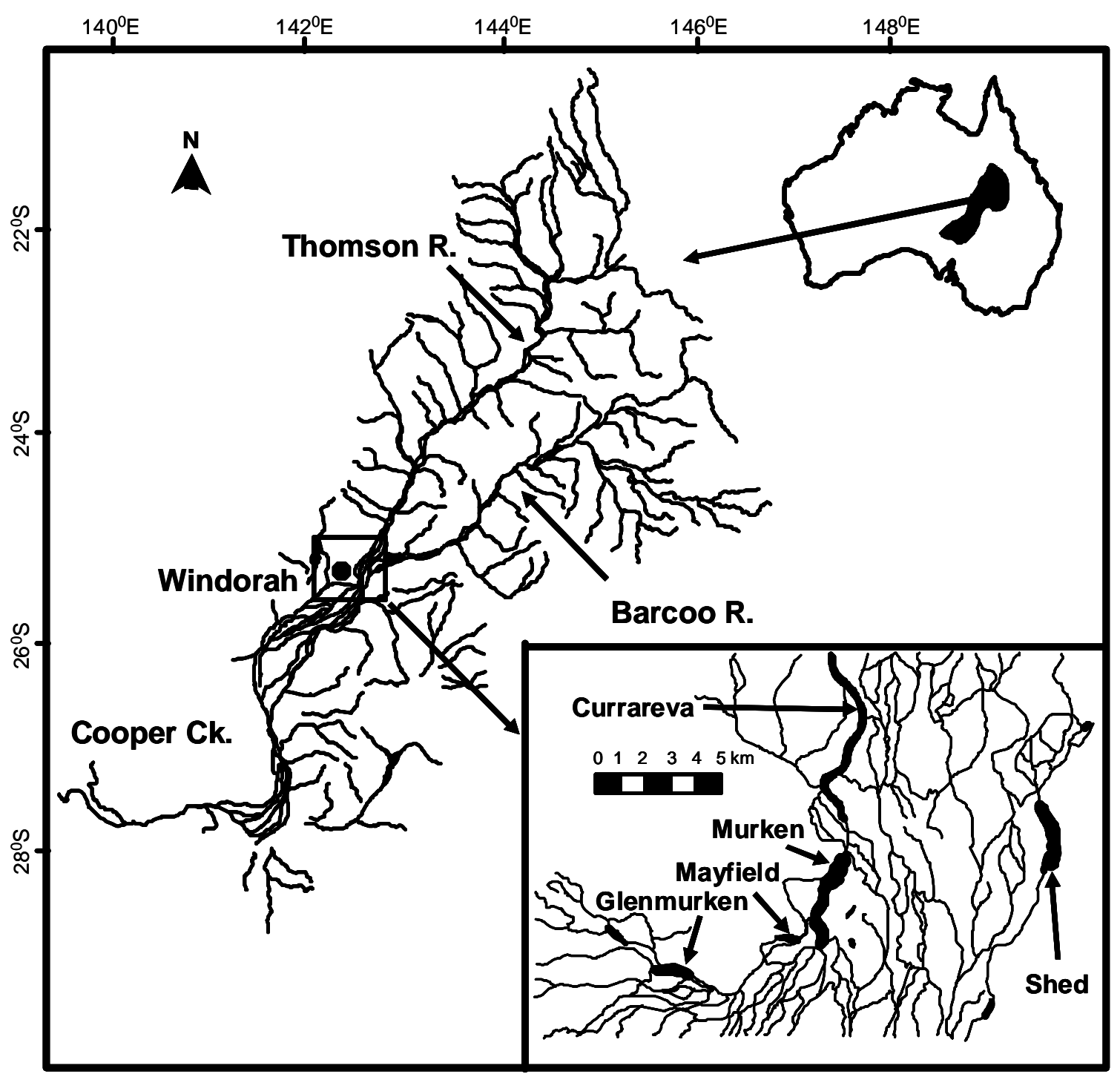




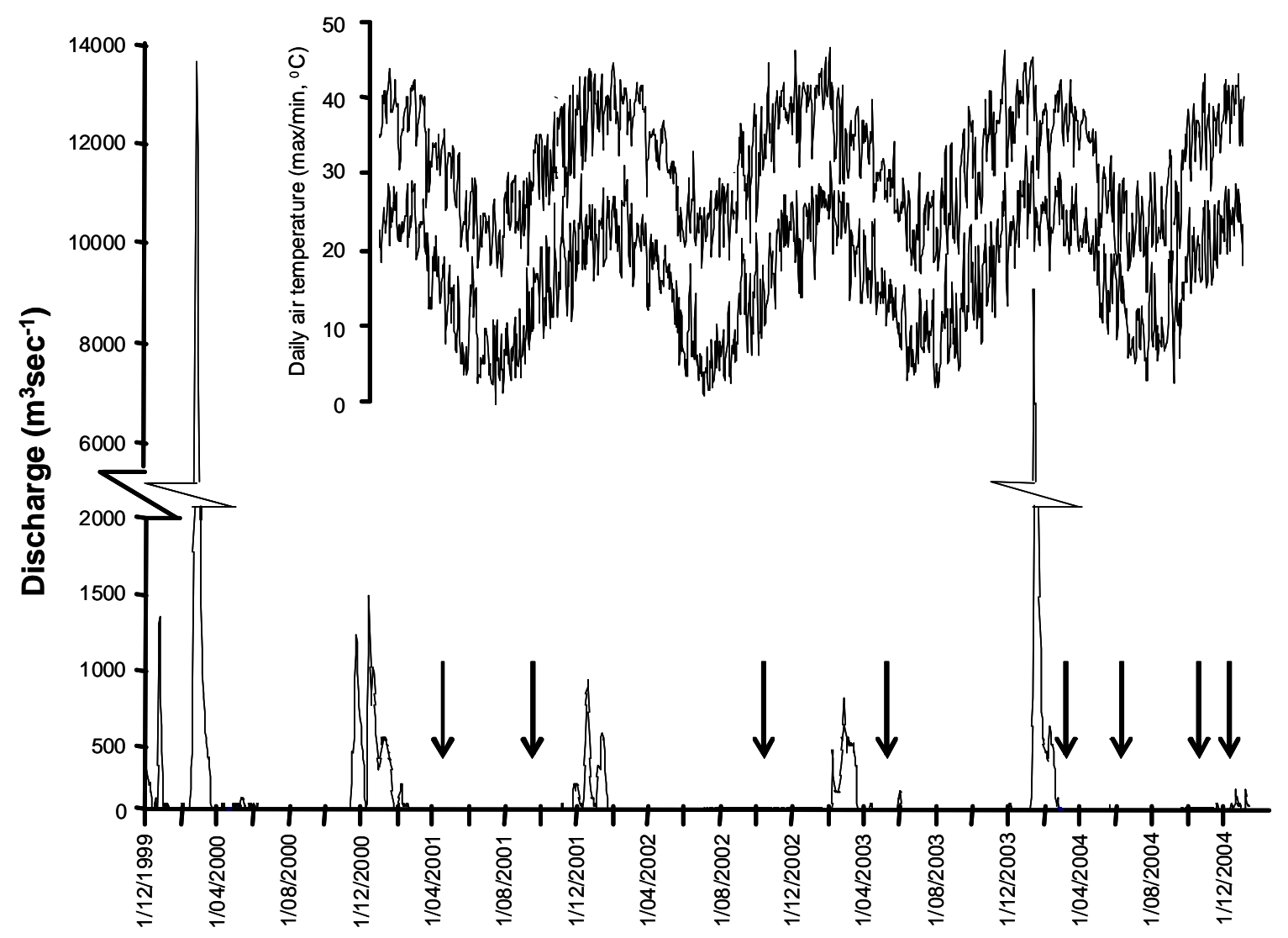



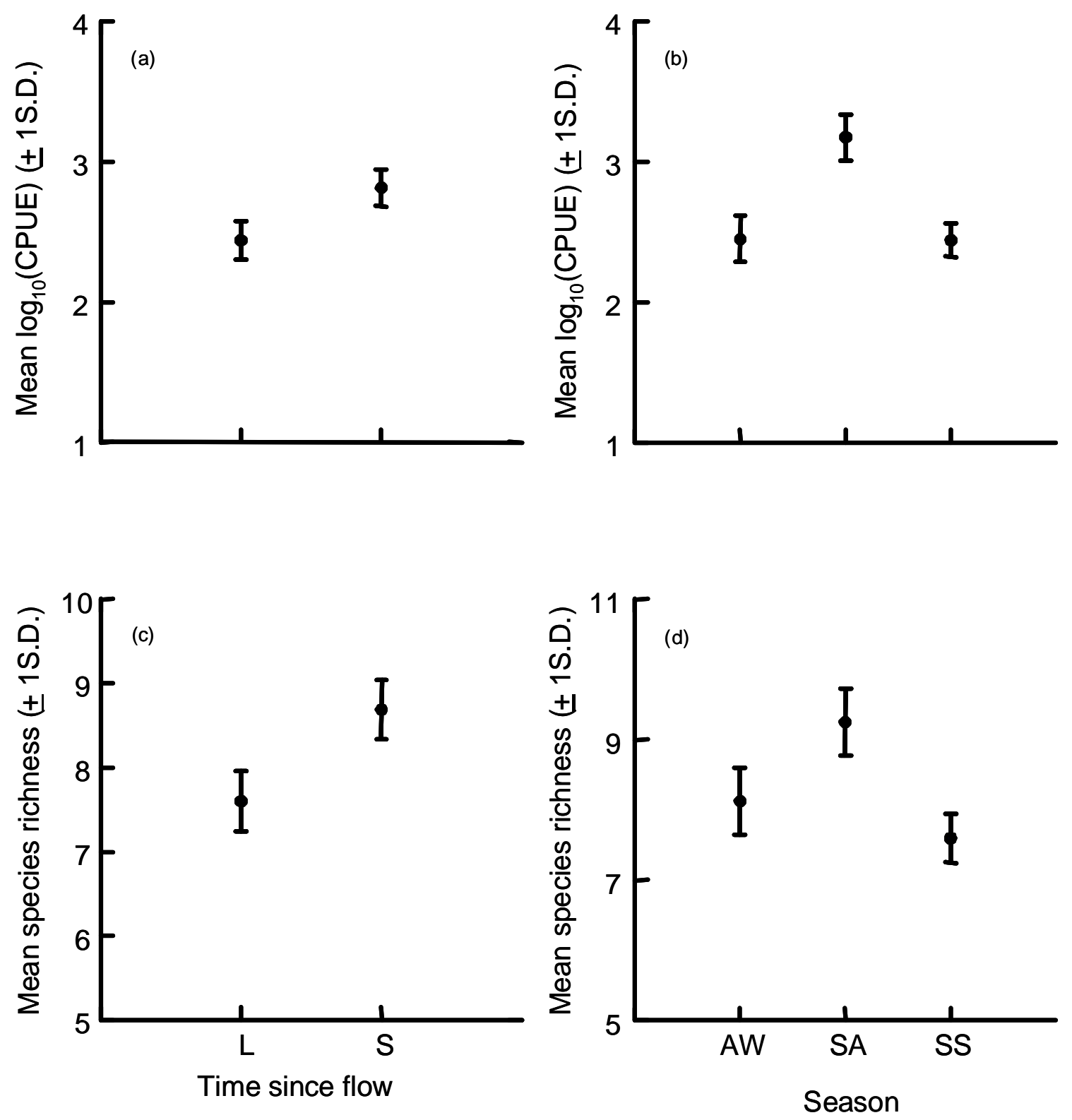


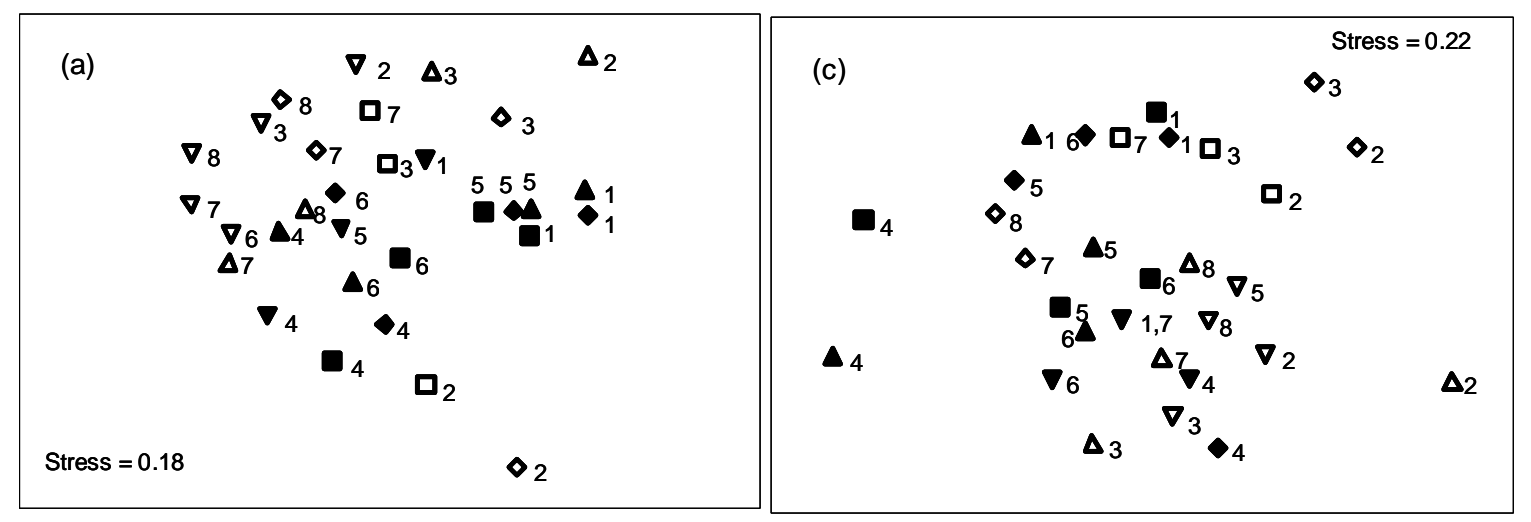

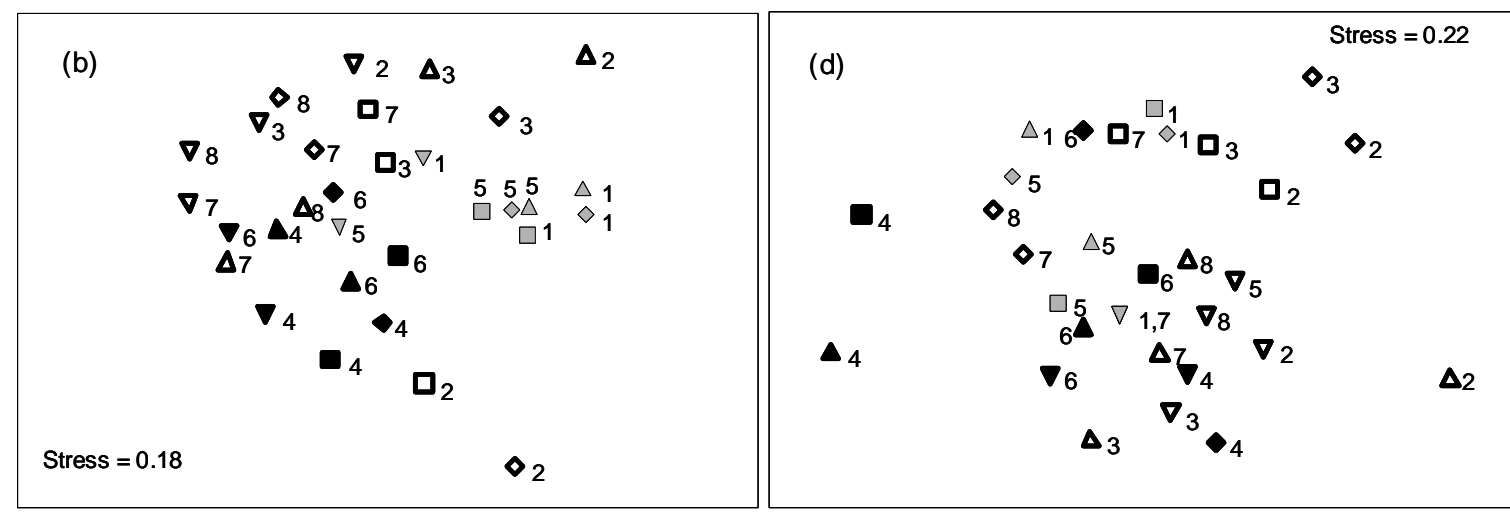

Waterhole: $\boldsymbol{\Delta}$ Murken $\boldsymbol{\nabla}$ Shed $\boldsymbol{\square}$ Glenmurken $\diamond$ Mayfield

Sampling times: 1=April 2001, 2=September 2001, 3=October 2002, 4=May2003,

5= March 2004, 6=June 2004, 7=October 2004, 8=December 2004 

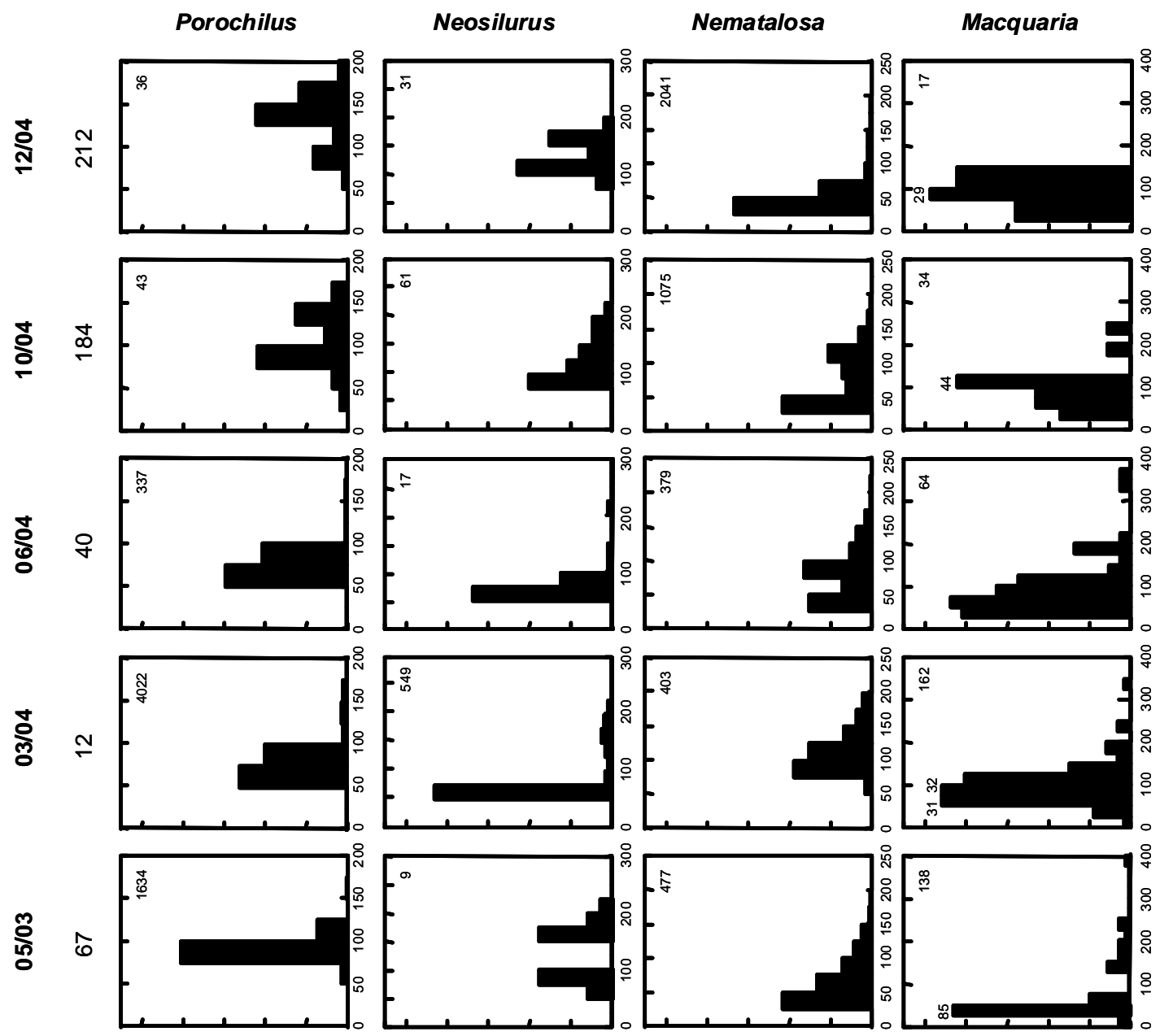

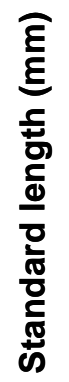
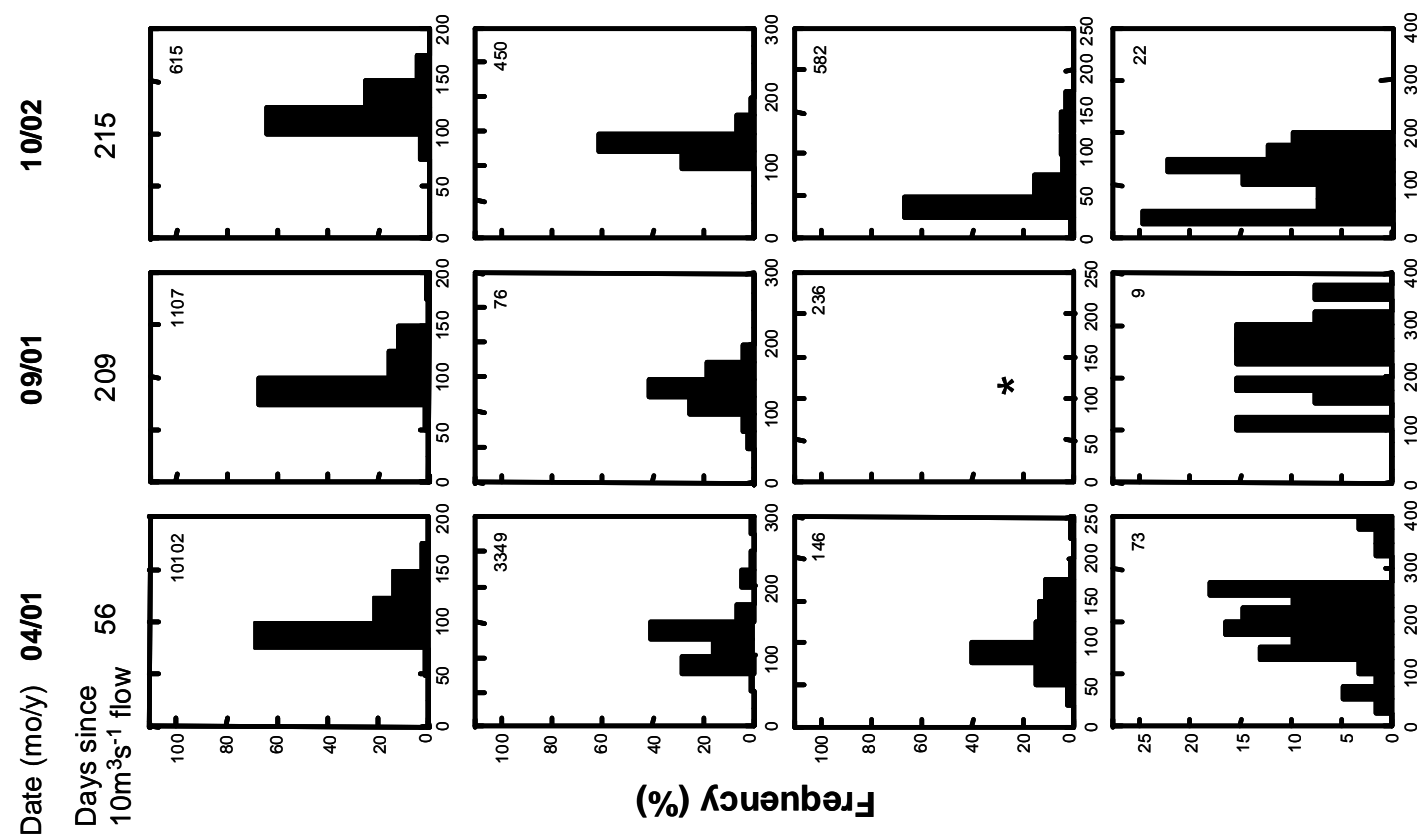

(\%) Кэuәnbəدత 